\title{
Human Dignity from Inherent to Constitutional Value
}

\author{
Irina Krylatova* \\ Chair of the Constitutional Law, Center of Bioethics and Law, Ural State Law University, 620137 Ekaterinburg, Russian Federation
}

\begin{abstract}
Human dignity is the nature of a human being. It became a modus of human existence, which differentiates humans from other biological species. Human life and human dignity are declared the priority values in international conventions and declarations. Intrinsic character of human dignity was the forerunner for the development of the new multidiscipline named bioethics in the XX century. This article begins with the basics of international regulations in the field of human dignity, definitions, analysis of main characteristics and doctrines of human dignity, inherent values and constitutional values. Further the author stresses the importance of understanding the meaning of inherent human dignity in connection with manipulations with somatic rights. The author concludes that the lack of human life and human dignity evaluation is the main point of the core principle of inherent human dignity based on personal selfawareness. In this regard the article focuses on the statement that human dignity should be an absolute value based on bioethical principles. Then the author goes on to compare constitutional values and human dignity as a value. The research is concluded with the suggestion that inherent human dignity is a base of constitutional values in the particular field of legal relations. In addition, inherent dignity may be the framework of constitutional values.
\end{abstract}

\section{Introduction}

Almost all the basic international conventions and declarations appeal to the inherence of human dignity. The notion of human dignity is inseparably connected with the cornerstones of modern human rights thinking that is the United Nations Universal Declaration of Human Rights of 1948 (UDHR), together with the International Covenant on Economic, Social and Cultural Rights and the International Covenant on Civil and Political Rights in 1966.

The mainstream of their articles is the inherent value of human dignity. The Preamble of the Universal Declaration of Human Rights (1948) (UDHR) proclaims that "recognition of the inherent dignity and of the equal and inalienable rights of all members of the human family is the foundation of freedom, justice and peace in the world... the General Assembly, Proclaims this Universal Declaration of Human Rights as a common standard of achievement for all peoples and all nations".

We find the similar story in the Convention for the Protection of Human Rights and Dignity of the Human Being with regard to the Application of Biology and Medicine. These are the Convention on Human Rights and Biomedicine, 1997; Universal Declaration on Bioethics and Human Rights, 2005; Universal Declaration on the Human Genome and Human Rights, 1997; International Declaration on Human Genetic Data,
2003, in the European Convention on Human Rights, 1950 .

The above-mentioned legal acts expand the content of dignity as the category and enrich the definition of inherent human dignity with regard to the rapid developments in science and biotechnology.

Bearing in mind that European Convention on Human Rights, 1950 made the repeated reference to human dignity from the Universal Declaration of Human Rights and underlined that the aim of the Council of Europe to be pursued is the maintenance and further realization of Human Rights and Fundamental Freedom. In contrast to the previous Convention, the Convention on Human Rights and Biomedicine several times mentioned even in preamble the importance of human dignity in relation to the accelerating developments in biology and medicine.

The Convention on Human Rights and Biomedicine shifts the focuses: human dignity still exists as a universal standard and value but at the same time the Convention underlines the biological nature of human dignity. Challenges of new biotechnologies and medical experiments linked with somatic rights raise a number of concerns in judicial society. Among them considered as urgent threat is prevention of denying the importance and inherence of human dignity. In particular, the preamble of the Convention on Human Rights and Biomedicine states that the member States of the Council of Europe, the other States and the European Community, are convinced of "the need to respect the

Corresponding author: krylatova_iy@mail.ru 
human being both as an individual and as a member of the human species". In addition, they recognize "the importance of ensuring the dignity of the human being, that the misuse of biology and medicine may lead to acts endangering human dignity".

Similarly, in 1997 the Universal Declaration on the Human Genome and Human Rights, 1997 confirmed the worry of international law society and remarked that "the recognition of the genetic diversity of humanity must not give rise to any interpretation of a social or political nature which could call into question 'the inherent dignity". Any research should fully respect human dignity, freedom and human rights and prohibit all forms of discrimination based on genetic characteristics. The document underlines that maintaining human dignity as the democratic principle must be founded upon the intellectual and moral solidarity of humankind.

It seems that appealing to the moral basics of human dignity which exists as the nature of dignity is the mainstream of contemporary legal trends. This tendency is reflected in later legal documents with respect to human dignity in biomedicine and bioethics, such as International Declaration on Human Genetic Data, 2003 and especially Universal Declaration on Bioethics and Human Rights, 2005.

The listed declarations expressed these ideas ahead of time. They pay attention to principles already stated in the Universal Declaration on the Human Genome and Human Rights and the International Declaration on Human Genetic Data and take account not only of the current scientific context but also of future developments, where human beings are an integral part of the biosphere. Universal Declaration on Bioethics and Human Rights, 2005 proclaims the statement that moral sensitivity and ethical reflection should be an integral part of the process of scientific and technological developments. Moreover, bioethics should play a predominant role in the choices that need to be made concerning issues arising from such developments. The ethics of human dignity as a universal value is inseparable from the autonomy and individual responsibility as could be inferred from the articles of Universal Declaration on Bioethics and Human Rights, 2005.

On the face of it, these affirmations and reaffirmations of respect for human rights and human dignity testify to a consolidation of the project started by the United Nations. In particular, they testify to human rights and human dignity being universally supported as fundamental values for the conduct of public life as well as for the governance of science, medicine and tectological development [1]. International documents underline that recognition of the declarations should be understood in a manner consistent with domestic and international law in conformity with human rights law.

The common provisions of human dignity as a value and priority of public policy are written in the Constitution of the Russian Federation (articles 7, 21, 72, 75.1). In particular, "human dignity shall be protected by the State. No one may be subject to medical, scientific and other experiments without voluntary consent".
It means that at the international and national levels there is no humanity without dignity.

In other words, the universalism of human dignity respect includes the complex matter of this category. On the one hand, respect and ensuring human dignity are the universal international standard; on the other hand, human dignity is the core value for the fundamental human rights and freedoms.

Bearing in mind that the inherent human dignity is the core legal principle and the background of human rights, it is a surprising fact that international and Russian documents avoid defining the term "inherent human dignity". At best, they list the indicators of inalienable human dignity.

To define the framework of the nature of inherent human dignity and compare it with the category of constitutional value, it is necessary to discuss several issues:

-the nature of inherent human dignity and its transformation in somatic human rights in the biotechnological challenges;

-the sufficiency of the current definition of human dignity;

- the nature of constitutional values and possibility of inherent human values as the platform of the constitutional values;

-and finally, the boundary between the inherent values and constitutional values in case of human dignity.

\section{Results and Discussion}

\section{Nature of values and human dignity}

Values as one of the main social and legal regulations have the hierarchal structure and universalism.

Some authors adhere to utilitarian approach and see values as public and personal interests [2], measures of address of needs [3], positive validity of object [4].

Others see the ideal world and ague that values are a phenomenon of special reality [5], values could be criteria, benefits which could be made up and exist as ideal being [6]. For this reason the researchers make the conclusion that the concept of value is the ideal existing cooperating with transcendental human's consciousness which is overpersonal and normative [7].

The third group of researchers focus their attention on public consciousness and self-awareness. In other words, they underline the fact that values are the sustainable belief that one type of human behavior is more valuable in a particular culture than others. Values exist in social consciousness and are internalized by a person [8].

This way of thinking most accurately reflects the common definitions of human dignity. In general, human dignity is a list of biological, religious, moral, national, cultural and social qualities, which a person values for oneself oriented to the existing public society standard. These qualities individualize a human as a personality and differentiate one from nature [9]. 
As a result, a value cannot be separated from the process of evaluation when a person actualizes some values and rejects others. Altogether, values should not be mixed with evaluation because morality is overpersonal, fundamental and autonomous [10]. Otherwise, the principle of universalization of human life and human dignity value will not exist. The lack of human life and human dignity evaluation is the main point of the core principle of inherent human dignity based on personal self-awareness. Thus, human dignity should be absolute, not a subjective or relative value.

\section{Inherent human dignity (from definition to transformation)}

Nowadays we see the attempts of defining the inherent human dignity and human dignity as legal and moral categories without specifying somatic human rights in the biotechnological challenges.

Somatic human rights which are defined by $\mathrm{M}$. Lavric as human confidence to manage a person`s body [11] have recently become the urgent core issue in the era of medical achievements. Another author - V. Kruss, points out that the subject of somatic claims has the material (physical) aspects as well as personal characteristics of (owner) (possessor) [12]. These features of somatic rights lead to their classification by the mentioned lawyers as a new human rights generation. Therefore, it automatically transforms the understanding and the interpretation methods of understanding of human dignity.

New human rights generation and the latest biomedical and biotechnological challenges affect the research and manipulations with human embryo, human cells and tissues (including growing chimeras, enhancement and CRISPR-Cas scissors) as well as the improvement of transplantology.

Only in the last six years such discoveries have been made and such experiments have been carried out as:

United Kingdom (2016, UK, Kathy Niakan, Crick University) - experiments on life-capable embryos have been allowed through genetic manipulations with DNA to exclude the hazard of miscarriage in pregnancy.

Mexico (2016, John Zhang, New York University and New Hope Fertility Center) - statement of the researcher John Zhang about the birth of the first child from 3 parents (Mitochondrial DNA of the mother has been replaced for a donor one to eliminate the risk of transferring a serious genetic disease to the child).

USA (2017, USA Jun Wu and Juan Carlos Izpisua Belmonte, Salk Institute, California) - creation of human chimeras by Juan Carlos Izpisua Belmonte implantation of genetically modified human cells into pig embryos. The share of the human cells in the embryos constituted less than $0.001 \%$, the rest were pig cells. Despite this, the embryos were allowed to develop for only 28 days, this was the first experience of growing human organs inside animals.

China (2018, China, He Jiankui, The Southern University of Science and Technology) - birth of genome-edited twins, for whom a part of DNA has been replaced for HIV 'protection', which was possessed by their father.

In 2021 the USA scientists were trying to avoid legal and ethical bounders by reprogramming fibroblasts cells into pluripotent stem cells, but nowadays this method is not widely spread, so the embryonic stem cells are one of the most needed commodities.

Stem cell genome editing by the CRISPR-Cas method known as "genetic scissors" (this genome editing technique enables scientists to remove and add pieces of genetic material with exquisite precision) nowadays allow one to create the universal pluripotent stem cells which can be used in such treatment as: blood diseases, repair damaged heart muscle, treating corneal diseases. Simultaneously such method allows one to solve the problem of shortage of organs for transplantation and treatment and forecast the orphan and endemic diseases.

Accessibility of such technologies of world recognition by awarding the Nobel Prize in Chemistry to Jennifer Doudna and Emmanuelle Charpentier in 2020 has open the new era of humankind in biology, health and medicine. The era where academic definition of human rights and human dignity values transform from theoretical disputes to practical everyday bioethical involvement. Such biomedical achievements raise not only the issue of boundaries of manipulation on human but lead to rethinking of biological, moral and judicial human rights and dignity basic concepts. The question of sufficiency of ethical and legal regulation of core moral values is raised.

That is why it is necessary to understand the sufficiency of definitions of inherent human dignity and human dignity as legal and moral categories.

What is the inherent human dignity as a value? This is not a question that admits an easy answer. The difficulty of defining the human dignity as an inalienable value lies in its complex nature. Human dignity is a social, psychological, cultural, religious, bioethics and legal phenomenon.

On the face of it, some authors make the attempt to determine human dignity as:

-phenomena of legal awareness and cultures [13];

-moral and legal value [14];

-moral value [15];

-universal constitutional category based on valuable social guidelines [16, 29];

-modus of being $[17,30]$;

- unified system of values [18] etc.

In this light, the inherent value of human dignity should be initially connected with the existing human as biological species, with human autonomy and integrity. Second, even setting aside the dispute of special safeguards and care of human dignity before as well as after birth, human dignity needs to be protected from the first opportunity when the medical and biotechnological achievements allow one to do this. Third, the human dignity inalienability ought to be based on human autonomy and integrity that are the core principles of bioethics. In this regard human dignity as the inherent value might be defined as modus of human being based on bioethical principles. 
Challenges of new biomedical technologies focus on the problem of enjoyment somatic or bioethical rights. This causes the necessity of seeking new approaches of defining the nature of inherent human dignity in the somatic area. I consider that in such case the value of human dignity inalienability should be focused on bioethical principles: autonomy, integrity, noninterference and informative concern. Science moves faster than moral understanding, as it does today, men and women struggle to articulate their unease about these matters [19]. Therefore, in brief, the existing definition of human dignity is not sufficient or should be transformed with the view of biomedical and bioethical proposals.

\section{The nature of constitutional values (features and basics)}

Discussion of the nature of the constitutional values mainly is polemical and axiological. One of the constant issues is the possibility of the inherent human values to be the platform of the constitutional values and the constitutional norms; and the thesis of permissibility of the individual moral behavior or moral public norms, which accompany human dignity, to be the heart of constitutional values.

Authors define constitutional values as the essence of legal values [20]. There are three main points of view on this topic. Some believe that constitutional values display the full cognition of legal regulation of personal, social and governmental activity. In addition, it seems that constitutional value is the model of axiological constitutional base which can be fixed and found in the constitutional legislation [21, 31].

Other academics consider the constitutional values to be the system of constitutional material and spiritual values that are perceived by the human being as the most valuable in personal and social life [22].

Still others define constitutional values as common guidelines or legal state principles [23], society-wide dogmas with legal connotation [24].

In summary, constitutional values are moral and legal guidelines that are written in constitutions or having the form of constitutional legal norms. Recognizing the moral ethic character of constitutional value, I suggest that inherent human dignity is a base of constitutional values in the particular field of legal relations. In addition, inherent dignity may be the framework of constitutional values because constitution is the main framework legal act. It is known that the constitution is the public contract between various social groups, confessions, cultures, nationalities and etc. In such case, the constitutional norms could not accommodate the whole specter of personal perceptions of human dignity and its uniqueness. That does not mean the refusal of attempt of fixing the inherent human dignity as universal moral guidelines and universal values of each state.

\section{Trying to seek the border between the inherent values and constitutional values}

Finally, we have to define the boundary between the inherent values and constitutional values in case of human dignity.

For this purpose, it is a good idea to look at judicial decisions. For example, the European Court of Human Rights is trying to develop the universal value standards during argumentation. Meanwhile the Constitutional Court of the Russian Federation bases its decisions on values that are above the constitutional norms and principles. This leads to the conclusion that the national constitutional values are objective barriers for the process of constitutional universality. There are differences between rational and values approaches [25]. At the same time, there is danger in the value approach. All the values have the hierarchy; therefore, the constitutional value might have the inside competition. Most vividly, it is recognized in judicial decisions where a private personal value (human dignity) outweighs the public order and public health as social values [26].

Furthermore, an appeal to the value is one of general judicial approaches in the Russian Federation. Judges of the Constitutional Court of the Russian Federation base their decisions on the basic assumption that human dignity is the core principle of public policy and quality of life. Accordingly, each person and governmental institution should defend human dignity and create the conditions of enjoyment human rights and human dignity. It is true in legal collisions, competence disputes and social and somatic rights [27].

Consequently, human dignity became the metacategory with legal polymorphism [28]. In other words, human dignity as well as bioethics are the umbrella terms. In this case, is it possible to set up the border between inherent values and constitutional values in human dignity aspect? I suppose that it is a rather complex matter. Law and constitutional law are the instruments of legal consolidation of values.

Therefore, constitutional values are result of this fixation. In contrast, inherent values and inherent human dignity as a value don't need fixation. The inherent values exist in moral field. If so, the establishing human dignity as constitutional value might be the suitable method of agreement between a person, public and government. Moreover, this fixation should be ensured by the effective mechanism of human rights protection. The inherent human dignity is the category that tends to be the moral tradition, moral custom, guidelines that could not be settled by legal norms and constitutional norms. Likewise, human dignity ought to be absolute but not a priority value and the border between the inherent human dignity and constitutional human dignity should not be justified by public or social interests.

\section{Conclusion}

In the age of biotechnology, the problems of defining the nature and the limits of human dignity have become not theoretical, but practical issues.

Moreover, one of the aims of legal regulation is to promote respect for human dignity. It seems that seeking cooperation and exhibiting the moral sense that gives 
expression to ethical principles in the rapid developments in science and technology increasingly affect our understanding of life and life itself.

Inherent and legal values are flexible structures, such as morality and law. That is why the issue of normative features of inherent dignity as a constitutional value is one of the urgent matters in somatic rights.

On the one hand, values might be a catalyst; on the other hand, they could limit human rights that is why it is necessary to apply and interpret them carefully by courts and general public.

As I suggested earlier, there is a possibility of competition inside the values and the constitutional values, but the same process is impossible between inherent and constitutional values. Inherent and constitutional values are not the equal phenomena. Inherent human dignity as an inalienable value is the base of constitutional values; therefore, the balance and competition between them are impossible.

The study was carried out with a grant from the federal budget on the implementation of a scientific project "Identification of regulatory problems in the use of genetic and genomic information. Preparation of scientifically based proposals for changes in the Russian legislation"( topic code FEUW-20200005).

\section{References}

1. M. Duwell, J. Braarvig, R. Brownsword, D. Mieth, The Cambridge Handbook of Human Dignity: Interdisciplinary Perspectives (Cambridge, Cambridge University Press, 2014), pp. 1-2.

2. Y.A. Demidov, Social Values and Evaluations in the Criminal Law, p. 50 (Legal Literature, Moscow, 1975)

3. V.N. Kudryavzev, Law, Conduct, Responsibility, p. 64 (Science, Moscow, 1986)

4. P.M. Rabinovich, Socialist Law as a Value, p. 9 (High School, Lviv, 1985)

5. L.S. Mamut, Social Sciences and Contemporary World, 4, 49 (1996)

6. I.D. Mishina, Moral Values in Law, p. 28 (Yekaterinburg, 1999)

7. I.D. Mishina, Moral Values in Law, p. 28 (Yekaterinburg, 1999)

8. V. I. Suprun, Science and Value, p. 162 (Science, Novosibirsk, 1987)

9. V.V. Nevinsky, Human Dignity: from Philosophical Idea to Constitutional Principle, p. 21 (Altai University Press, Barnaul, 1999)

10. I.D. Mishina, Moral Values in Law, p. 37, p. 174 (Yekaterinburg, 1999)
11. M.A. Lavrik, To the theory of somatic rights, Siberian Law Herald, 3, 16 (2005)

12. V.I. Kruss, Personal (somatic) human rights in philosophical-constitutional dimension: to the problem statement, State and Law, 10, 43-50 (2000)

13. T.A. Hashem, Human Dignity Defense, p. 5 (Moscow, 2012)

14. O.V. Vlasova, Human Dignity as Moral and Legal Value: Theoretical Research (Khanty-Mansiysk, 2011)

15. V.V. Kuznezov, Dignity as Moral Value (St. Petersburg, 1998)

16. V.E. Guliev, F.M. Rudinsky, Democracy and Human Dignity (Science, Moscow, 1983)

17. Rawls, Political Liberalism (Colombia University Press, New York, 1993)

18. R. Dworkin, Justice for Hedgehogs (Cambridge, MA, Harvard University Press, 2011).

19. M. Sandel, The case against Perfection. Ethics in the Age of genetic Engineering (Cambridge, MA, Harvard University Press, 2007), p. 3

20. V.V. Nevinsky, Lex Russia, 11(44), 106-121 (2018)

21. S.A. Avakyan, The Thoughts of a Constitutionalist, pp. 351-363 (Moscow University Press, Moscow, 2010)

22. V.V. Nevinsky, Constitutional and Municipal Law, 12, 56-65 (2018)

23. O.A. Snezko, Comparative Constitutional Review, 2, 13 (2005)

24. A.A. Kondrasev, Constitutional and Municipal Law, 1, 6-13 (2017)

25. S. A. Belov, Comparative Constitutional Review, 4(101), 50-51 (2014)

26. I. Karaseva, Comparative Constitutional Review, 4(101), 80 (2014)

27. Decision of the Constitutional Court of the Russian Federation of May 25, 2021 No. 22-P; Decision of the Constitutional Court of the Russian Federation of January 19, 2021 No. 1-O; Decision of the Constitutional Court of the Russian Federation of February 10, 2016 No. 224-O.

28. I.A. Kravez, State and Law, 1, 41-53 (2020)

29. A.V. Belyavsky, N.A. Pridvornov, The Defense of Honor and Dignity in USSR (Legal Literature, Moscow, 1971)

30. The Law of Peoples: With, The Idea of Public Reason Revisited (Cambridge, M.A.: Harvard University Press, 2001).

31. N.S. Bondar, Journal of Constitutional Justice, 6(12), 1-11 (2009) 